\title{
Author Correction: Joint disease-specificity at the regulatory base-pair level
}

Pushpanathan Muthuirulan, Dewei Zhao, Mariel Young, Daniel Richard, Zun Liu, Alireza Emami, Gabriela Portilla, Shayan Hosseinzadeh (D, Jiaxue Cao, David Maridas, Mary Sedlak, Danilo Menghini, Liangliang Cheng, Lu Li, Xinjia Ding, Yan Ding (1), Vicki Rosen (10, Ata M. Kiapour (1) \& Terence D. Capellini (1)

Correction to: Nature Communications https://doi.org/10.1038/s41467-021-24345-9, published online 6 July 2021.

In this article the funding from 'the Faculty Council at Boston Children's Hospital' was omitted. The original article has been corrected.

Published online: 27 January 2022

(c) (i) Open Access This article is licensed under a Creative Commons Attribution 4.0 International License, which permits use, sharing, adaptation, distribution and reproduction in any medium or format, as long as you give appropriate credit to the original author(s) and the source, provide a link to the Creative Commons license, and indicate if changes were made. The images or other third party material in this article are included in the article's Creative Commons license, unless indicated otherwise in a credit line to the material. If material is not included in the article's Creative Commons license and your intended use is not permitted by statutory regulation or exceeds the permitted use, you will need to obtain permission directly from the copyright holder. To view a copy of this license, visit http://creativecommons.org/licenses/by/4.0/.

(C) The Author(s) 2022 